\title{
FEATURE
}

\section{What is causing the harmful algal blooms in Lake Erie?}

\author{
Douglas R. Smith, Kevin W. King, and Mark R. Williams
}

I

n the early to mid-1990s, Lake Erie was regarded as one of the great water quality success stories stemming from the Clean Water Act. Annual total phosphorus (TP) loading to the lake decreased from nearly 30,000 t $(33,069$ tn) in the late-1960s to less than $11,000 \mathrm{t}$ $(12,125$ tn) by 1990 (Richards and Baker 1993). These reductions in TP loading were achieved through permitting of point sources and through conservation efforts to decrease sediment loss from agricultural fields. While TP loads to Lake Erie have remained relatively stable since the mid-1990s, soluble phosphorus (SP) loads have been steadily increasing. The harmful and nuisance algal blooms (HNABs) that paralyzed regional tourism and fishing industries decades ago have reappeared and have been linked with the amount of SP transported to the lake (Davis et al. 2009). In August of 2014, HNABs in Lake Erie became a national headline when microcystin toxin produced by cyanobacteria was discovered and approximately 400,000 residents in Ohio were left without drinking water.

There has been much debate among researchers, conservationists, and industry representatives on the specific causes of the increased HNABs in Lake Erie. Our objective here is to document many of the recently suggested theories that connect natural and agricultural contributions to the increasing SP loading to the lake. It is important to recognize, however, that HNABs are likely due to the complex interactions among multiple factors rather than any one specific factor. Thus, the presentation of suggested theories that follows is not in order of causality as there is no way to separate out which issue is of greatest concern.

Douglas $\mathbf{R}$. Smith is a research soil scientist at the USDA Agricultural Research Service (ARS), Grassland, Soil and Water Research Laboratory, Temple, Texas. Kevin W. King and Mark R. Williams are research agricultural engineers at the USDA ARS, Soil Drainage Research Unit, Columbus, Ohio.
Climate Change. The majority of phosphorus $(\mathrm{P})$ transport from agricultural fields to receiving waters occurs during storm events. In the past 10 to 15 years, spring rainfall has increased by approximately $25 \%$, and the size and intensity of these events have also increased (Kevin King, personal communication, December 15,2014).As a result, more $P$ is being delivered to Lake Erie during the spring season, which is critical for HNAB formation.

Commodity Prices. Commodity prices over the past five years have been substantially greater than historical prices (Tyner 2010). Greater commodity prices provide incentive for producers to increase $\mathrm{P}$ application rates in order to minimize the perceived risk of crop loss due to inadequate P fertility (i.e., insurance applications).

Cropping System. Cropping systems have transitioned from 4- to 10-year rotations with many crops, including hay and/or multiple small grain crops, to a 2-year corn (Zea mays L.)-soybean (Glycine max L.) rotation or a 3-year corn-soybean-wheat (Triticum aestivum L.) rotation. Since 1974, corn and bean acreage in Ohio have increased 15\% and $48 \%$, respectively, while wheat, other small grains, and hay have seen $66 \%, 89 \%$, and $22 \%$ declines in acreage, respectively (USDA NASS 2014). Less diverse cropping systems require greater nutrient inputs and result in lower soil quality.

Crop Nutrient Efficiency. Advancements in crop genetics have resulted in crop varieties with greater nutrient use efficiencies (Gaxiola et al. 2011), while fertilizer recommendations have remained unchanged (Vitosh et al. 1995). Thus, current fertilizer recommendations may result in $\mathrm{P}$ application rates in excess of crop demand.

Ethanol Production. Demand for agriculture to produce more biofuel (Tyner 2010) has increased the number of acres planted in continuous corn and corn-soybean rotations. More nutrients are applied to corn compared to other crops; thus, there is a greater potential for P loss.

Fertilizer Placement. Phosphorus fertilizers are often surface applied through broadcast applications, which results in minimal contact between the soil and fertilizer. Broadcast applications present a significantly greater risk of $\mathrm{P}$ loss compared to fertilizer that is incorporated into the soil.

Fertilizer Rates. Producers often apply enough $\mathrm{P}$ fertilizer for both crops in corn-soybean rotation prior to the corn crop. While this strategy has led to fewer fields receiving fertilizer each year, there is more $\mathrm{P}$ available to be lost on the fields that have been fertilized. In addition, crop consultants and fertilizer dealers often recommend that $\mathrm{P}$ fertilizer should be applied at crop removal rates even if soil testing indicates there will be no response to the P fertilizer.

Tri-State Recommendations. The tristate fertilizer recommendations include a factor of safety to ensure producers do not lose yield potential and to account for differences across soil types (Vitosh et al. 1995). Thus, on the productive soils in the Western Lake Erie Basin (WLEB), P is likely applied to fields at rates greater than crop demand since the tests are calibrated for all soils in Ohio, Michigan, and Indiana, including less productive soils (Nizeyimana et al. 2001).

Fertilizer Source. In the mid-1990s, there was a switch from triple superphosphate (TSP) to diammonium phosphate (DAP) and monoammonium phosphate (MAP) fertilizers. These three fertilizers are more than 90\% SP, but the MAP and DAP are not as acidic as TSP, which may lead to greater $\mathrm{P}$ losses. It is also difficult to calibrate equipment to apply DAP and MAP at rates below $112 \mathrm{~kg} \mathrm{ha}^{-1}\left(100 \mathrm{lb} \mathrm{ac}^{-1}\right)$.

Fertilizer Timing. Phosphorus fertilizers are often applied during the nongrowing season (November to April). The lack of crop nutrient uptake combined with the fact that the nongrowing season is the most hydrologically active period of the year substantially increases the risk of $\mathrm{P}$ loss in storm runoff.

RoundUp Ready Crops. Glyphosate, the active ingredient in RoundUp, has been adopted by many producers since RoundUp Ready crop varieties have 
been introduced. Glyphosate has a phosphate $\left(\mathrm{PO}_{4}\right)$ group in the molecule that can readily attach to the soil (Laitinen et al. 2008); therefore, glyphosate applications may increase the amount of $\mathrm{P}$ available for transport. Additionally, it has been suggested that the long-term use of glyphosate may alter soil microbial communities and microbial processing of $\mathrm{P}$.

Increased Soil $\boldsymbol{p H}$. Following the Clean Air Act, the $\mathrm{pH}$ of rainfall has increased from 4.4 to 5.2 over the past several years, which has also increased soil pH (NADP 2014). Phosphorus availability in soil is directly related to soil $\mathrm{pH}$; less acidic soils result in greater $\mathrm{P}$ availability and potentially greater P loss. The switch from TSP to MAP and DAP fertilizers may exacerbate this problem.

Larger Farms. Over the past 30 years, average farm size has substantially increased, with many producers now farming several thousand acres annually. In 1982, there were 52,659 farms reporting corn grain harvested, and in 2012, only 24,789 farms reported harvesting corn for grain (USDA NASS 2014). Larger farms have smaller windows of opportunity to complete field operations, and $\mathrm{P}$ applications are more often completed during the nongrowing season when the risk of $\mathrm{P}$ loss is the greatest. On large farms, P may also be applied at rates sufficient to provide two or three crops with ample nutrients.

Lower Levels of Sediment in the Water. Declining sediment loads delivered to Lake Erie (Richards et al. 2009) as the result of conservation practices adopted in the 1980 s may result in greater SP losses. Less sediment from upland sources may increase erosion of bank sediments saturated with $\mathrm{P}$ in streams as the flowing water attempts to achieve the sediment transport capacity of the system. Lower levels of sediment may also decrease the $\mathrm{P}$ buffering capacity of the river network, resulting in greater $\mathrm{P}$ delivery to the lake.

Manure. Manure application is often cited as a reason for the increase in HNABs in Lake Erie. Some portions of the WLEB contain large numbers of animal feeding operations, and manures can represent a chronic source of $\mathrm{P}$ to receiving waters, particularly from soils where manures were applied at disposal rates for many years and have resulted in high soil test $\mathrm{P}$ concentrations.

Misconceptions about Phosphorus Loss. Many researchers have dismissed the amount of $\mathrm{P}$ being lost from agriculture over the past two decades since SP concentrations in water are often $1 / 100^{\text {th }}$ of the observed nitrate-nitrogen $\left(\mathrm{NO}_{3}-\mathrm{N}\right)$ concentrations. Phosphorus loads of $1.12 \mathrm{~kg}$ $\mathrm{ha}^{-1}\left(1 \mathrm{lb} \mathrm{ac}^{-1}\right)$ have also been deemed agronomically insignificant. However, these $\mathrm{P}$ concentrations and loads are equivalent to the levels causing the HNABs in Lake Erie (Chaffin et al. 2011; Smith et al. 2015a).

Nitrogen. There are some species of algae, including Microcystis, that produce the microcystin toxin that do not fix their own N (Chaffin et al. 2011). Excess N delivery to Lake Erie from agricultural sources may therefore lead to greater numbers of algae that produce the microcystin toxin and thereby exacerbate the magnitude and extent of the HNAB problem in the lake.

No-Till. It has been observed that the increase in SP loading to Lake Erie coincided with the peak adoption of no-till (mid-1990s). While no-till was a primary factor in decreasing sediment and TP delivery to the lake, no-till can result in the formation of preferential flow paths, especially on the heavy clay soils of the WLEB. No-till and the formation of preferential flow paths can result in increased P loading through subsurface drainage (Smith et al. 2015a).

Rental Agreements. Much of the land in the WLEB is not farmed by the owner, and as part of many rental agreements, the owner requires the producer to maintain the nutrient status of the soil. In Indiana, $54 \%$ of all farm ground is rented (Reimer et al. 2012). Thus, even if the fields have sufficient or excess $\mathrm{P}$, the producer must apply $\mathrm{P}$ at the crop removal rate.Also, rental agreements are generally not long-term contracts; therefore, structural conservation practices are rarely implemented on rented land.

Products Sold to Increase Soil Phosphorus Solubility. Recently, products have been developed and marketed as fertilizer additives that improve the bioavailability of soil P. Often microbes in the soil coupled with root physiology are sufficient to provide a crop with the necessary $\mathrm{P}$; thus, using these products may make more $\mathrm{P}$ available than the crop can use, which would then be available for off-site transport. Further, it is unknown if the active ingredients are available for transport and what effects they may have in aquatic environments.

Alterations to Soil Biology. To meet world food demand, genetically modified organisms (GMOs) were introduced to provide greater crop consistency. Changes to the sugars and proteins of the crop produced different cultivars, and the residue becomes the diet of soil microbes when the crops are harvested (Flores et al. 2005). It has been suggested that the altered microbe diet or alterations to the microbial population resulting from GMOs may impact the processing of $\mathrm{P}$ and potentially make it more soluble compared to 15 years ago.

Soil Testing and Analysis. Calibration of soil tests were completed before many of the recent advancements in agriculture (Vitosh et al. 1995). For example, when these tests were developed tillage was commonplace, and SP losses were not an important water quality issue. Therefore, many soil tests recommend $\mathrm{P}$ application rates greater than crop removal rates. Further complicating this factor is the lack of standard laboratory and reporting procedures, which may readily lead to misinterpretation of results.

Stratification of Phosphorus. In fields where P fertilizer has been surface broadcast for years and not incorporated, $\mathrm{P}$ tends to be found at greater concentrations near the surface compared to lower strata (Kleinman et al. 2003), and this finding has been observed in WLEB soils (Laura Johnson, personal communication, January $6,2015)$. Higher P concentrations in surface soils pose a significant risk of $\mathrm{P}$ loss in surface runoff and in subsurface drainage, as preferential flow paths can provide a direct connection between surface soils rich in $\mathrm{P}$ and tile drains.

Tile Drainage. Recent studies of $\mathrm{P}$ transport in tile drainage have shown that tile drains account for a large proportion of SP delivered from agricultural fields to streams (King et al. 2015; Smith et al. 2015b). The extent and intensity of tile 
drainage has been increasing due to economic gains realized from commodity prices, increased crop yields, and better crop growth in tile drained fields. Thus, increases in tile drainage throughout the WLEB may result in increased SP loads delivered to Lake Erie.

Zebra Mussels. Lake Erie has been invaded by Zebra mussels (Dreissena polymorpha) (Hecky et al. 2004), which filter sediment and algae, and excrete bioavailable P. They also tend to "spit out" many of the algae associated with HNABs, including the species that produce the microcystin toxin. Zebra mussels may therefore cause higher concentrations of microcystin-producing algae relative to other species of algae and intensify the HNAB problem in the lake.

\section{OUTLOOK AND RECOMMENDATIONS}

Current Lake Erie water quality issues are the result of the complex interactions among economic, management, climatic, and political factors. The theories of causes of HNABs in Lake Erie documented in this article exclude urban and suburban factors, which are also important contributors of $\mathrm{P}$ loads to the lake. This perfect storm of $\mathrm{P}$ issues in the WLEB has become a public health issue on a grand scale, and as a result, it is imperative in terms of agricultural contribution that producers, agronomic advisors, scientists, industry professionals, and policy makers work in concert to solve this issue. We believe the imminent research needs are to (1) better define fertility recommendations that optimize agronomic and environmental outcomes; (2) seek fertilizers and application technologies that will maintain crop productivity while minimizing $\mathrm{P}$ losses; and (3) work at the landscape scale to minimize P losses at locations within fields, at the edge of fields, in the riparian corridor, and in the stream continuum.

As we move forward, we must recognize some unfortunate truths. For example, management for TP does not necessarily mean we will improve losses of SP. Management of these two forms of $\mathrm{P}$ is often contradictory. As we change and improve the agronomic system, we must also be aware of the unintended consequences of our actions. Lastly, the changes we make today may not lead to decreasing $\mathrm{P}$ loads tomorrow. There is a tremendous amount of $\mathrm{P}$ already in the system, and lag times for $\mathrm{P}$ transport can vary from a few months to greater than 10 years. While we do not intend to paint the situation as hopeless, we must make progress today if we want to see future improvement in the water quality of Lake Erie.

\section{REFERENCES}

Chaffin, J.D., T.B. Bridgeman, S.A. Hechathorn, and S. Mishra. 2011. Assessment of Microcystis growth rate potential and nutrient status across a trophic gradient in western Lake Erie. Journal of Great Lakes Research 37:92-100, doi: 10.1016/j. jglr.2010.11.016.

Davis, T.W., D.L. Berry, G.L. Boyer, and C.J. Gobbler. 2009. The effects of temperature and nutrients on the growth and dynamics of toxic and nontoxic strains of Mycrocystis during cyanobacteria blooms. Harmful Algae 8:715-725

Flores, S., D. Saxena, and G. Stotzky. 2005. Transgenic Bt plants decompose less in soil than non-Bt plants. Soil Biology and Biochemistry 37(6):10731082, doi:10.1016/j.soilbio.2004.11.006.

Gaxiola, R.A., M. Edwards, and J.J. Elser. 2011. A transgenic approach to enhance phosphorus use efficiency in crops as part of a comprehensive strategy for sustainable agriculture. Chemosphere 84:840-845, doi: 10.1016/j. chemosphere.2011.01.062.

Hecky, R.E., R.E.H. Smith, D.R. Barton, S.J. Guildford, W.D. Taylor, M.N. Charlton, and T. Howell. 2004. The nearshore phosphorus shunt: A consequence of ecosystem engineering by dreisseneids in the Laurentian Great Lakes. Canadian Journal of Fisheries and Aquatic Sciences 61(7):1285-1293.

King, K.W., M.R. Williams, and N.R. Fausey. 2015. Contributions of systematic tile drainage to watershed phosphorus transport. Journal of Environmental Quality. In Press, doi: 10.2134. jeq2014.04.0149.

Kleinman, P.J.A., B.A. Needelman, A.N. Sharpley, and R.W. McDowell. 2003. Using soil phosphorus profile data to assess phosphorus leaching potential in manured soils. Soil Science Society of America Journal 67(1):215-224.

Laitinen, P., K. Siimes, S. Ramo, L. Jauhiainen, L. Eronen, S. Oinonen, and H. Hartikainen. 2008. Effects of soil phosphorus status on environmental risk assessment of glyphosate and glufosinateammonium. Journal of Environmental Quality 37(3):830-838, doi: 10.2134/jeq2007.0256.
NADP (National Atmospheric Deposition Program). 2014. Hydrogen Ion Wet Deposition. http:// nadp.sws.uiuc.edu/maplib/ani/Hplus_ani.pdf.

Nizeyimana, E.L., G.W. Petersen, M.L. Imhoff, H.R. Sinclair Jr., S.W. Waltman, D.S. Reed-Margetan, E.R. Levine, and J.M. Russo. 2001. Assessing the impact of land conversion to urban land use on soils with different productivity levels in the USA. Soil Science Society of America Journal. 65:391-402

Reimer, A.P., D.K. Weinkauf, and L.S. Prokopy. 2012. The influence of perceptions of practice characteristics: An examination of agricultural best management practice adoption in two Indiana watersheds. Journal of Rural Studies 28:118-128, doi:10.1016/j.jrurstud.2011.09.005.

Richards, R.P., and D.B. Baker. 1993. Trends in nutrient and sediment concentrations in Lake Erie tributaries, 1975-1990. Journal of Great Lakes Research 19:200-211.

Richards, R.P., D.B. Baker, and J.P. Crumine. 2009. Improved water quality in Ohio tributaries to Lake Erie: A consequence of conservation practices. Journal of Soil and Water Conservation 64(3):200-211, doi:10.2489/jswc.64.3.200.

Smith, D.R., W. Francesconi, S.J. Livingston, and C. Huang. 2015a. Phosphorus losses from monitored fields with conservation practices in the Lake Erie Basin, USA. Ambio 44(Supplement 2):S319-331, doi:10.1007/s13280-014-0624-6.

Smith, D.T., K.W. King, L. Johnson, W. Francesconi, P. Richards, D. Baker and A.N. Sharpley. 2015b. Surface runoff and tile drainage transport of phosphorus in the Midwestern United States. Journal of Environmental Quality. In Press, doi: 10.2134/jeq2014.04.0176.

Tyner, W.E. 2010. The integration of energy and agricultural markets. Agricultural Economics 41(1):193-201.

USDA NASS (USDA National Agricultural Statistics Service). 2014. National Agricultural Statistics Service. http://www.nass.usda.gov/.

Vitosh, M.L., J.W. Johnson, and D.B. Mengel. 1995 Tri-State Fertilizer Recommendations for Corn, Soybeans, Wheat and Alfalfa. https://www.extension.purdue.edu/extmedia/AY/AY-9-32.pdf. 